Article

\title{
Synthesis, Characterization, and Photovoltaic Properties of Soluble TiOPc Derivatives
}

\author{
Young-Keun Kim ${ }^{1,2}$, Hyo-Jin Kang ${ }^{1}$, Young-Wook Jang ${ }^{1,2}$, Su-Bin Lee ${ }^{1}$, Seung-Min Lee ${ }^{1}$, \\ Ki-Suck Jung ${ }^{1,3}$, Jin-Kook Lee ${ }^{1, *}$ and Mi-Ra Kim ${ }^{1, *}$
}

1 Department of Polymer Science and Engineering, Pusan National University, Busan, 609-735, South Korea

2 Polycen Co., Ltd., Busan, 608-739, South Korea

3 Daehan Solvay Special Chemicals Co., Ltd., Ulsan, South Korea

* Authors to whom correspondence should be addressed; E-Mails: leejk@pusan.ac.kr (J. L.), mrkim2@pusan.ac.kr (M. K.); Tel. +82-51-510-3045; Fax: +82-51-513-7720

Received: 20 November 2008; in revised form: 16 December 2008 / Accepted: 18 December 2008 / Published: 19 December 2008

\begin{abstract}
We have synthesized soluble TiOPc derivatives containing alkoxy groups for use as additives in dye-sensitized solar cells (DSSCs). The DSSC devices containing these TiOPc derivatives exhibited short-circuit current densities of $8.49 \sim 10.04 \mathrm{~mA} / \mathrm{cm}^{2}$ and power conversion efficiencies of $2.73 \sim 3.62 \%$ under AM 1.5 illumination and $100 \mathrm{~mW} / \mathrm{cm}^{2}$ irradiation.
\end{abstract}

Keywords: Titanyl phthalocyanine (TiOPc); Dye-sensitized solar cell; Polymer electrolyte.

\section{Introduction}

Dye-sensitized solar cells (DSSCs) constructed using dye molecules, nanocrystalline metal oxides and organic liquid electrolytes were originally developed by the research group of Gratzel et al. [1-6]. DSSCs have attracted much attention around the world, due to their high power conversion efficiency, easy fabrication, and low production cost. However, DSSCs have not been used in practical applications because many difficulties regarding their use of a liquid electrolyte remain unresolved, 
such as solvent evaporation, leakage and deterioration, which cause sealing problems and performance degradation. To solve these problems, solid-state electrolytes have been developed to replace these liquid electrolytes. Solid-state DSSCs do not need hermetic sealing, but their power conversion efficiency is lower than that of DSSCs with conventional organic liquid electrolytes. To improve their power conversion efficiency, attempts have been made to add various materials to the electrolyte [712]. Solid-state or quasi-solid-state electrolytes, such as hole-conducting molecular solids [13] and polymers [14], molten salts [15] and ionic liquids [16-17], have been investigated and used in place of the volatile organic solvent in DSSCs. In light of their unusual electrochemical and electronic properties, phthalocyanines (Pcs) are potentially useful additives. Pcs have attracted the attention of many researchers during the twentieth century and are still being actively studied in this century [1819]. Many potential applications are expected for phthalocyanines (Pcs), which have high thermal and chemical stability, for instance as solar cell functional materials, gas sensors, and photodynamic therapy agents. The results concerning DSSCs using TiOPc as a co-adsorbent have been previously reported [20]. However, many of the applications of Pcs have been limited by their lack of solubility in organic solvents and water. Over the past few decades, a large variety of substituted Pc derivatives have been synthesized in order to improve their solubility [21, 22].

In this study, we synthesized titanyl phthalocyanine (TiOPc) derivatives containing an alkoxy chain group with good solubility. The molecular structures of the synthesized TiOPc derivatives were characterized by Fourier Transform Infrared Spectrophotometry (FT-IR), Matrix Assisted Laser Desorption Ionization Time-of-Flight (MALDI-TOF) mass spectroscopy, X-ray Diffraction (XRD), and Transmission Electron Microscopy (TEM). The thermal properties of the TiOPc derivatives were analyzed by thermal gravimetric analysis (TGA) and differential scanning calorimetry (DSC) under a nitrogen atmosphere. The optical properties of the TiOPc derivatives were monitored by UV-vis spectrophotometry and fluorescence spectrophotometry.

We also studied the photovoltaic properties of the TiOPc derivatives. We prepared quasi-solid state dye-sensitized solar cell (DSSC) devices with TiOPc derivatives. These DSSC devices were fabricated using ruthenium (II) complex dye (N3 dye) as a photosensitizer and the TiOPc derivatives as additives in the electrolytes.

\section{Results and Discussion}

\subsection{Synthesis and characterization of TiOPc derivatives (3a and $\mathbf{3 b}$ )}

The TiOPc derivatives, 2,9,16,23-tridecyloxyphthalocyaninato oxotitanium(IV) (3a) and 2,9,16,23pentadecyloxyphthalocyaninato oxotitanium(IV) (3b) were prepared using the two-step synthesis described in Ref. [23]. The synthetic route of TiOPc derivatives is shown in Scheme 1. Their chemical structures were characterized by FT-IR. The characteristic alkyl group stretch at $2850-2950 \mathrm{~cm}^{-1}$ and ether stretch at $1250 \mathrm{~cm}^{-1}$ of 4-tridecyloxyphthalonitrile (2a) / 4-pentadecyloxyphthalonitrile (2b) appear upon the formation of the alkoxy group in alkoxyphthalonitriles. The characteristic nitrile $(\mathrm{C} \equiv \mathrm{N})$ stretch at $2232 \mathrm{~cm}^{-1}$ of 2 disappears upon the formation of the TiOPc. The split ether stretching frequencies are prominent for both the phthalonitriles and the phthalocyanines in the $1100-1264 \mathrm{~cm}^{-1}$ range. 
Scheme 1. The synthetic route to titanyl phthalocyanine (TiOPc) derivatives.

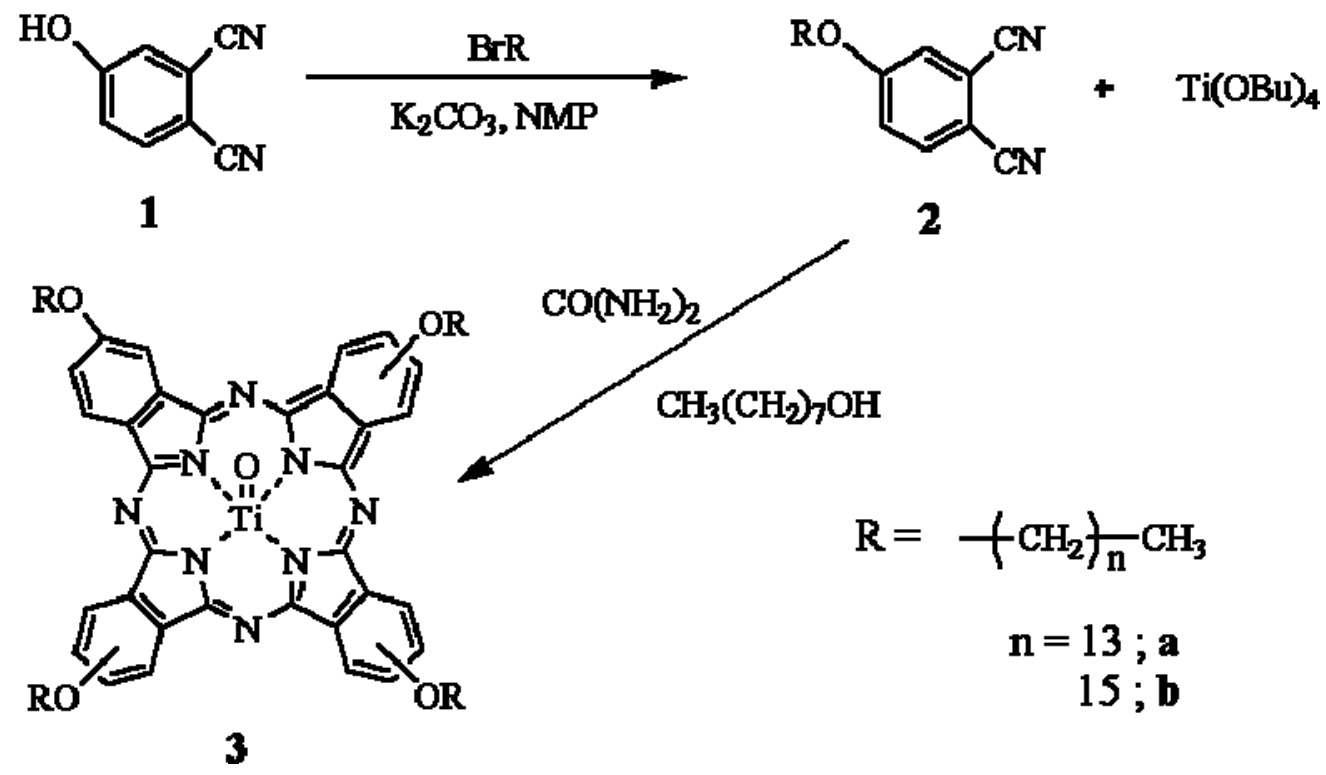

\subsection{Solubility of $\mathbf{3 a}$ and $\mathbf{3 b}$}

The solubilities of $\mathbf{3 a}$ and $\mathbf{3 b}$ were examined at a ratio of compound to solvent of $100 \mathrm{mg} / \mathrm{mL}$. Table 1 shows the solubilities of TiOPc, 3a, and $\mathbf{3 b}$ in a variety of common solvents. TiOPc was insoluble in almost all organic solvents. Compared with TiOPc, $\mathbf{3 a}$ and $\mathbf{3 b}$ exhibited increased solubility in various solvents, such as chloroform, chlorobenzene, and toluene, but not in methanol and acetone. In many applications, the solubility of materials is a very important problem. Therefore, the solubility of 3a and $\mathbf{3 b}$ in organic solvents makes them promising materials.

Table 1. Solubility of TiOPc, 3a, and 3b.

\begin{tabular}{cccc}
\hline Compounds & TiOPc & 3a & 3b \\
\hline $\mathrm{CHCl}_{2}$ & $\mathrm{I}$ & $\mathrm{S}$ & $\mathrm{S}$ \\
Chlorobenzene & $\mathrm{I}$ & $\mathrm{S}$ & $\mathrm{S}$ \\
Toluene & $\mathrm{I}$ & $\mathrm{S}$ & $\mathrm{S}$ \\
Acetone & $\mathrm{I}$ & $\mathrm{I}$ & $\mathrm{I}$ \\
Methanol & $\mathrm{I}$ & $\mathrm{I}$ & $\mathrm{I}$ \\
DMF & $\mathrm{I}$ & $\mathrm{I}$ & $\mathrm{I}$ \\
$\mathrm{THF}$ & $\mathrm{I}$ & $\mathrm{P}(17 \mathrm{wt} \%)$ & $\mathrm{P}(26 \mathrm{wt} \%)$ \\
\hline
\end{tabular}

*Solubility in $100 \mathrm{mg} / \mathrm{mL}$

$* \mathrm{~S}=$ soluble, $\mathrm{P}=$ partially soluble, $\mathrm{I}=$ insoluble 


\subsection{Optical properties of $\mathbf{3 a}$ and $\mathbf{3 b}$}

The absorption and fluorescence spectra of $\mathbf{3 a}$ and $\mathbf{3 b}$ in chloroform are shown in Figure 1. The absorption spectra of $\mathbf{3 a}$ and $\mathbf{3 b}$ showed broad bands in the region around $340 \mathrm{~nm}$ and sharp peaks at $704 \mathrm{~nm}$ and $705 \mathrm{~nm}$, respectively. Weak Q-band region peaks contributed by the aggregations appear in the 620-680 $\mathrm{nm}$ region. The spectra show the typical Soret and Q-bands, which are characteristic of phthalocyanines. Upon excitation at $640 \mathrm{~nm}$. Compounds 3a and $\mathbf{3 b}$ showed fluorescence emissions at 709 and $711 \mathrm{~nm}$, respectively.

Figure 1. Fluorescence (solid line) and absorption (dashed line) spectra of (A) 3a and (B) $3 \mathbf{b}$.
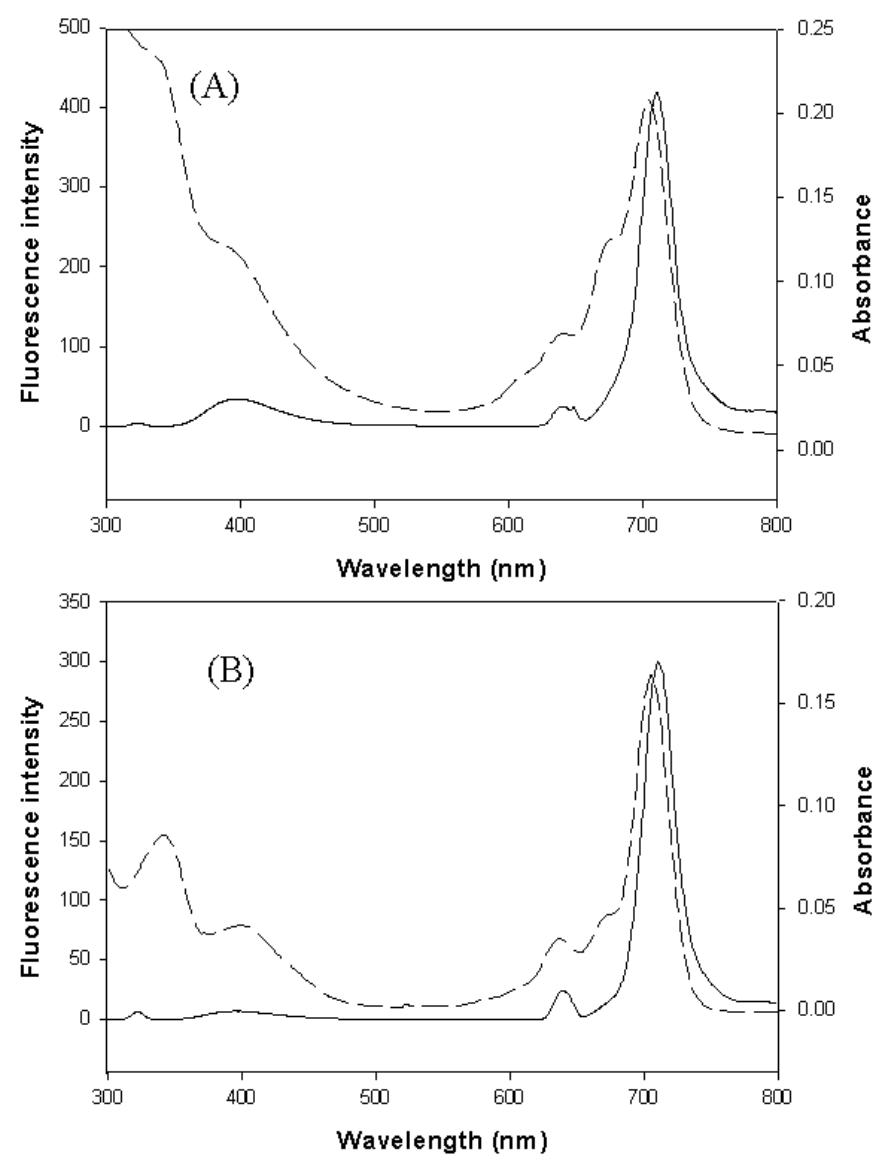

\section{4. $X R D$}

The XRD patterns of 3a and $\mathbf{3 b}$ measured in the range of 2 theta of 10-50 degrees (Table 2) show identical features with relatively poor crystallinity. Although the observed patterns resemble qualitatively that of the corresponding unsubstituted TiOPc, the peaks are found to be broadened with diffused intensity. This reveals that $\mathbf{3 a}$ and $\mathbf{3 b}$ were less crystalline than the unsubstituted TiOPc [24]. This may be due to the presence of the bulky substituent alkoxy chain, and seems to play a dominant role in the stacking of the metal phthalocyanine derivatives. The X-ray diffraction patterns were only used to explain the degree of crystallinity, which is qualitative. The effect of the alkoxy chain substitution can be clearly identified from the first $d$ values of all of the complexes. 


\subsection{TEM studies}

The size and morphology of the synthesized compounds were analyzed by TEM measurements. The TEM images of $\mathbf{3 a}$ and $\mathbf{3} \mathbf{b}$ are shown in Figure 2. The TEM micrography revealed that $\mathbf{3 a}$ and $\mathbf{3 b}$ consisted of irregular spherical nanoparticles with diameters ranging from $450 \mathrm{~nm}$ to $600 \mathrm{~nm}$ and that the particles were agglomerated.

Table 2. XRD data 2 theta angle and relative intensity of $3 \mathbf{a}$ and $\mathbf{3 b .}$

\begin{tabular}{ccc}
\hline Compounds & XRD data 2 theta angle (dA) & Relative intensity (\%) \\
\hline & $10.94(8.08)$ & 73 \\
$11.64(7.59)$ & 79 \\
$17.30(5.12)$ & 25 \\
$17.92(4.94)$ & 31 \\
$19.34(4.58)$ & 84 \\
$20.46(4.34)$ & 37 \\
$22.50(3.95)$ & 28 \\
3a & $22.84(3.89)$ & 38 \\
& $23.50(3.78)$ & 58 \\
$24.38(3.64)$ & 100 \\
$26.60(3.35)$ & 38 \\
\hline $11.32(7.81)$ & 83 \\
$13.22(6.69)$ & 41 \\
$16.82(5.27)$ & 38 \\
$18.04(4.91)$ & 33 \\
$18.48(4.80)$ & 96 \\
$19.76(4.49)$ & 63 \\
3b & $20.14(4.41)$ & 77 \\
& $21.28(4.18)$ & 27 \\
& $22.06(4.03)$ & 49 \\
$23.00(3.87)$ & 79 \\
$23.64(3.76)$ & 39 \\
$24.86(3.57)$ & 27 \\
$25.98(3.43)$ & 100 \\
\hline
\end{tabular}

Figure 2. TEM images of 3a (A) and $3 \mathbf{b}(\mathrm{B})$.

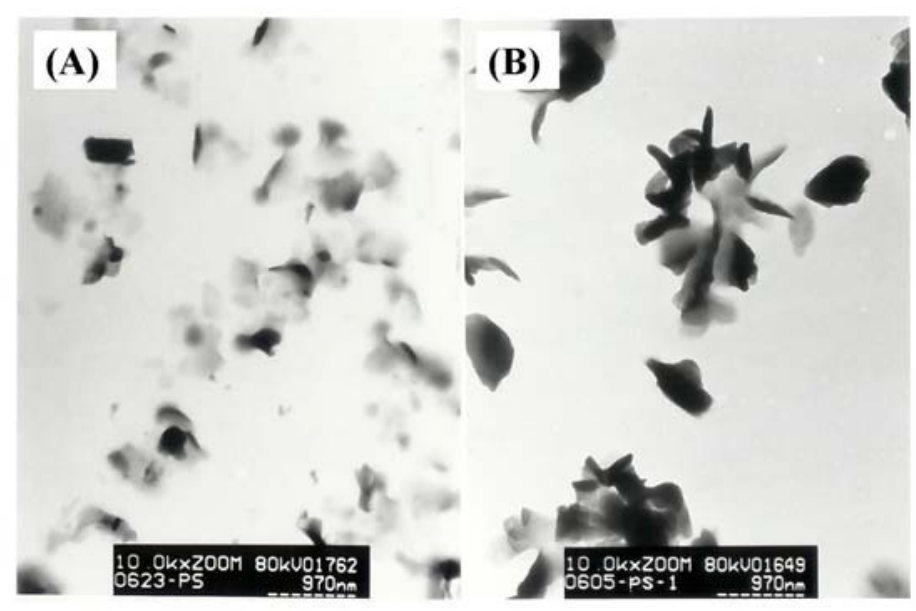




\subsection{AFM studies}

The surface morphology of 3a and $\mathbf{3 b}$ films was measured by atomic force microscopy (AFM). All of the films were prepared by the spin-coating method from a chloroform solution. The difference in the root mean square (RMS) surface roughness between the two films was not very large, as depicted in Figure 3. The RMS roughnesses of 3a and $\mathbf{3 b}$ were $2.22 \mathrm{~nm}$ and $10.59 \mathrm{~nm}$, respectively.

Figure 3. AFM images of 3a (A) and $3 \mathbf{b}(\mathrm{B})$; image sizes are $3 \mu \mathrm{m} \times 3 \mu \mathrm{m}$.
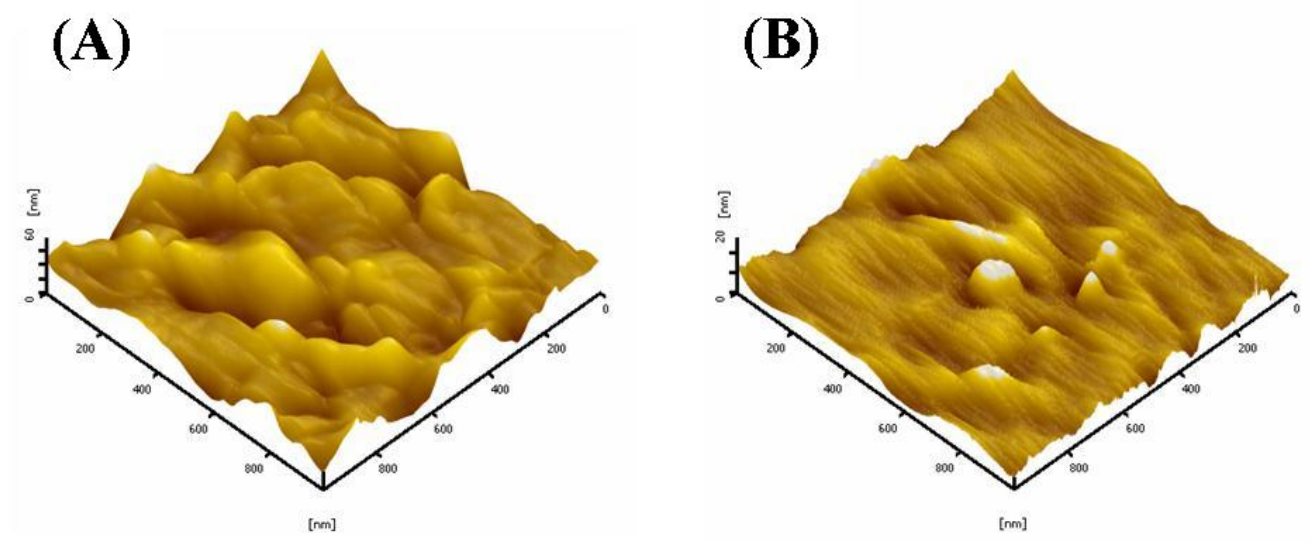

\subsection{TGA and DSC studies}

The TGA curves of $\mathbf{3 a}$ and $\mathbf{3 b}$ are illustrated in Figure 4. The typical TGA curve obtained with a heating rate of $10{ }^{\circ} \mathrm{C} / \mathrm{min}$ demonstrated high thermal stability up to $245^{\circ} \mathrm{C}$. The initial decomposition temperatures (Tds) of $\mathbf{3 a}$ and $\mathbf{3 b}$ were observed to be $213.65{ }^{\circ} \mathrm{C}$ and $256.11{ }^{\circ} \mathrm{C}$, respectively, which are less than that of TiOPc. This may be due to the substituted alkoxy chains of $\mathbf{3 a}$ and $\mathbf{3 b}$. Figure 5 shows the DSC curves of $3 a$ and $3 b$.

Figure 4. TGA curves of $3 \mathbf{a}$ and $3 \mathbf{b}$.

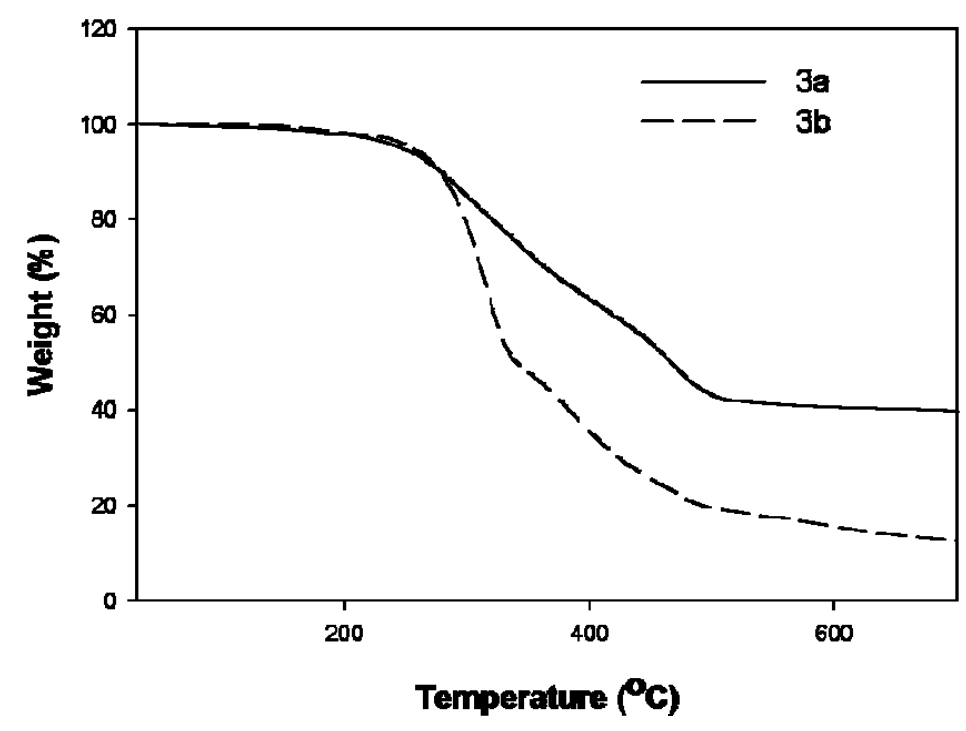


Figure 5. DSC curves of $\mathbf{3 a}$ and $\mathbf{3 b}$.

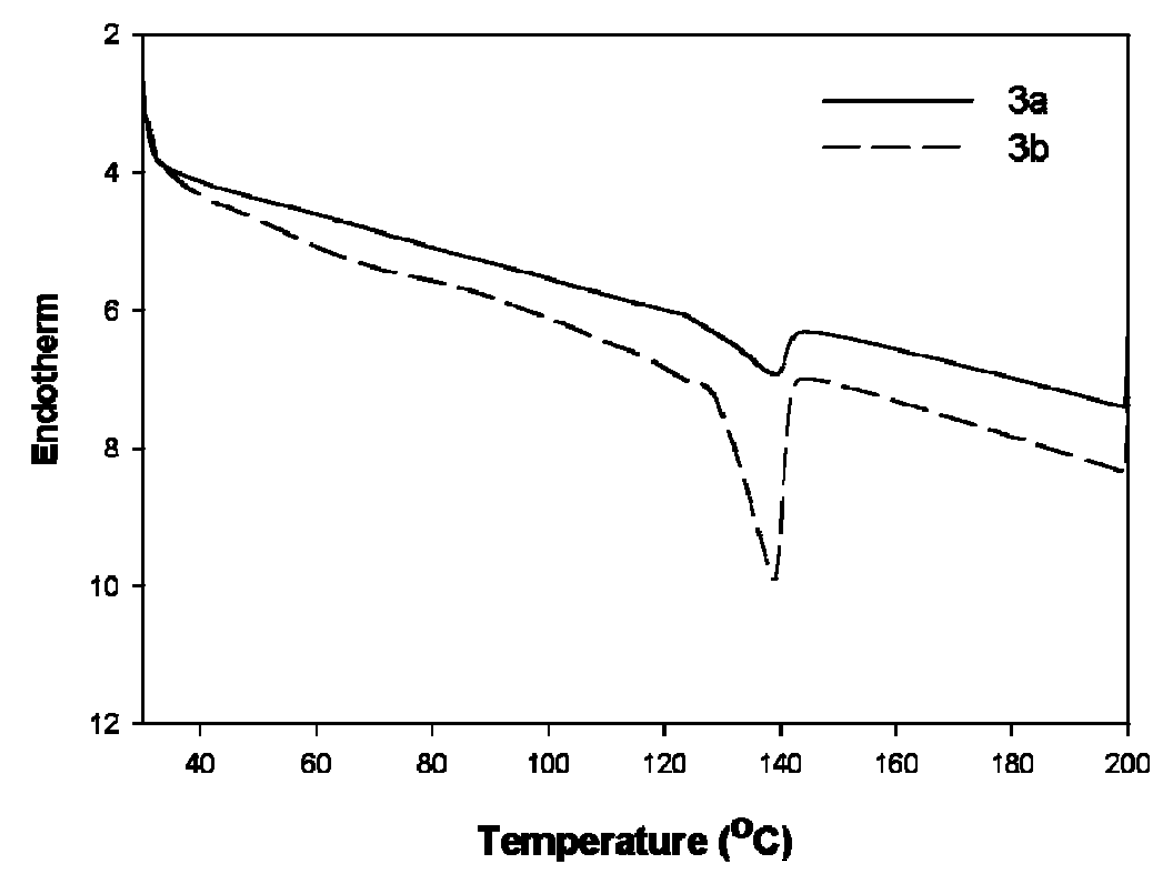

\subsection{Photovoltaic performances of DSSC devices}

The photovoltaic measurements were performed using a solar simulator under AM 1.5 illuminated conditions, and the active area of the DSSC devices was $0.25 \mathrm{~cm}^{2}$. The power conversion efficiency $(\eta)$ of a solar cell given by:

$$
\begin{gathered}
\eta=P_{\text {out }} / P_{\text {in }}=\left(J_{\text {sc }} \times V_{\text {oc }} \times F F\right) P_{\text {in }} \\
\text { with FF }=\left(I_{\max } \times V_{\text {max }}\right) /\left(J_{s c} \times V_{o c}\right)=P_{\text {max }} /\left(J_{s c} \times V_{o c}\right)
\end{gathered}
$$

where $\mathrm{P}_{\text {out }}$ is the output electrical power of the device under illumination and $\mathrm{P}_{\text {in }}$ represents the intensity of the incident light (e.g., in $\mathrm{W} / \mathrm{m}^{2}$ or $\mathrm{mW} / \mathrm{cm}^{2}$ ). $\mathrm{V}_{\mathrm{oc}}$ is the open-circuit voltage, $\mathrm{J}_{\mathrm{sc}}$ is the short-circuit current density, and the fill factor (FF) is calculated from the values of $\mathrm{V}_{\mathrm{oc}}, \mathrm{J}_{\mathrm{sc}}$, and the maximum power point, $\mathrm{P}_{\max }$. Figure 6 shows the $\mathrm{I}-\mathrm{V}$ curves of the $\mathrm{FTO} / \mathrm{TiO}_{2} / \mathrm{Dye} /$ Electrolyte$/ \mathrm{Pt}$ device using 3a or $\mathbf{3 b}$ as an additive. The DSSC devices using the TiOPc derivatives showed different results according to the methyl chain length. The values of $\mathrm{V}_{\mathrm{oc}}, \mathrm{J}_{\mathrm{sc}}, \mathrm{FF}$ and the power conversion efficiency $(\eta)$ are listed in Table 3. The $\mathbf{J}_{\mathrm{sc}} \mathrm{s}$ of the devices using 3a, 3a with PEG, 3b, 3b with PEG, and PEG were $8.49,9.84,10.02,10.04$, and $8.98 \mathrm{~mA} / \mathrm{cm}^{2}$, respectively. The power conversion efficiencies of the DSSC devices using 3a, 3a with PEG, 3b, 3b with PEG, and PEG was 2.73, 3.49, 3.19, 3.62, and $2.94 \%$, respectively. The DSSC devices using 3a and 3b with PEG showed higher photovoltaic performance than the devices using PEG without $\mathbf{3 a}$ and $\mathbf{3 b}$ in the same procedure. The $\mathbf{J}_{\mathrm{sc}}$ values of the DSSC devices using $\mathbf{3 a}$ and $\mathbf{3} \mathbf{b}$ were increased, and this can attributed to improvements in their power conversion efficiency. 
Figure 6. $\mathrm{I}-\mathrm{V}$ curves of $\mathrm{FTO} / \mathrm{TiO}_{2} /$ Dye/Electrolyte/Pt devices using 3a, 3a with $\mathrm{PEG}$, 3b, 3b with PEG, and PEG under AM 1.5 illumination; light intensity: $100 \mathrm{~mW} / \mathrm{cm}^{2}$; active area: $0.25 \mathrm{~cm}^{2}$; with mask.

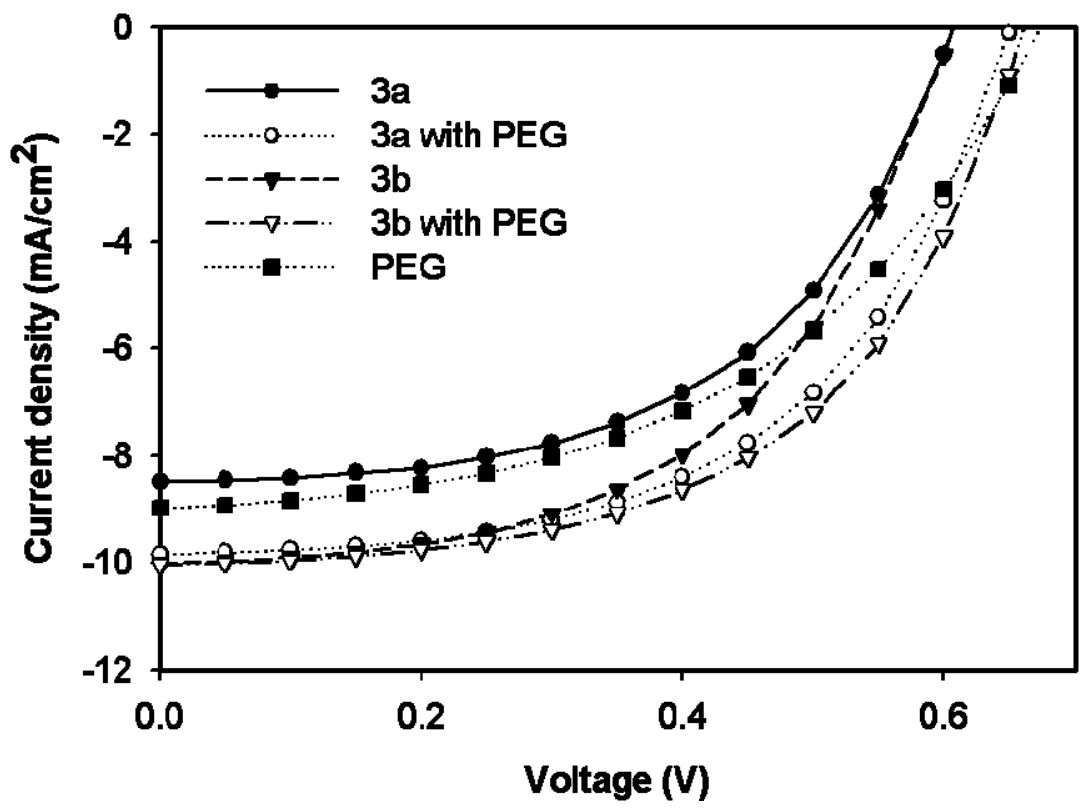

Table 3. The photovoltaic Performances of $\mathrm{FTO} / \mathrm{TiO}_{2} /$ Dye/Electrolyte/Pt Devices Using 3a, 3a with PEG, 3b, and 3b with PEG under AM 1.5 Illumination.

\begin{tabular}{ccccc}
\hline & $\mathbf{V}_{\mathbf{~ o c}}{ }^{\mathbf{1})}(\mathbf{V})$ & $\left.\mathbf{J}_{\mathbf{s c}}{ }^{\mathbf{2}} \mathbf{( \mathbf { m A }} / \mathbf{c m}^{\mathbf{2}}\right)$ & $\mathbf{F F}$ & Efficiency (\%) \\
\hline 3a & 0.61 & 8.49 & 0.53 & 2.73 \\
3a with $\mathrm{PEG}^{4)}$ & 0.65 & 9.84 & 0.54 & 3.49 \\
3b & 0.61 & 10.02 & 0.53 & 3.19 \\
3b with $\mathrm{PEG}^{4)}$ & 0.66 & 10.04 & 0.54 & 3.62 \\
PEG & 0.67 & 8.98 & 0.49 & 2.94 \\
\hline
\end{tabular}

${ }^{1)} \mathrm{V}_{\mathrm{oc}}(\mathrm{V})$ : Open circuit voltage. ${ }^{2)} \mathrm{J}_{\mathrm{sc}}\left(\mathrm{mA} / \mathrm{cm}^{2}\right)$ : Short circuit current density. ${ }^{3)}$ FF: Fill factor.

${ }^{4)}$ Compound : $\mathrm{PEG}=1.7(\mathrm{wt} \%)$.

\section{Experimental Section}

\subsection{Materials}

4-Hydroxyphthalonitrile, 1-bromohexadecane, 1-bromotetradecane, 1-octanol, 1-methyl-2pyrrolidinone (NMP), titanium(IV) butoxide $\left[\mathrm{Ti}(\mathrm{OBu})_{4}\right], \mathrm{I}_{2}$, tetrabutylammonium iodide (TBAI), ethylene carbonate (EC), and propylene carbonate (PC) were purchased from Sigma-Aldrich Co. Urea was purchased from Shinyo Pure Chemicals Co. All reagents were of analytical grade and used as received without further purification. $\mathrm{TiO}_{2}$ paste, viz. Ti-Nanoxide HT/SP (particle size: $9 \mathrm{~nm}$, wt 20 $\%$ ), cis-bis(isothiocyanato)bis(2,2'-bipyridyl-4,4'-dicarboxylato)-ruthenium(II) dye (N3 dye), F-doped $\mathrm{SnO}_{2}$ glass (FTO glass), Pt paste ( $\mathrm{Pt}$ catalyst T/SP), and 1-propyl-3-methylimidazolium iodide (PMImI), were purchased from Solaronix CA. 


\subsection{Measurements}

The FT-IR spectra (KBr pellets) were recorded on a Jasco FT/IR-460 Plus spectrometer. The ${ }^{1} \mathrm{H}$ NMR spectra $(300 \mathrm{MHz})$ were recorded in $\mathrm{CDCl}_{3}$ using a Varian Unity Plus $300 \mathrm{NMR}$ spectrometer. The UV-vis absorption and fluorescence spectra of the TiOPc derivatives in chloroform solution were recorded on a UVIKON 860 spectrophotometer and Hitachi F-4500 fluorescence spectrophotometer, respectively. The TEM images were recorded on a Hitachi H-7500 Transmission Electron Microscope. Scanning Probe Microscopy was performed using a NITECH Model SPA-400. The TGA and DSC analyses were conducted on a TA instruments (TGA-Q 50 and TGA-Q 100) thermal analyser at a heating rate of $10^{\circ} \mathrm{C} / \mathrm{min}$ under flowing nitrogen $(40 \mathrm{~mL} / \mathrm{min}$ and $50 \mathrm{~mL} / \mathrm{min})$. The measurement of the I-V characteristics of the solar cells was carried out using a Solar Simulator (300 W simulator, models 81150) under simulated solar light with an ARC Lamp power supply (AM 1.5, $100 \mathrm{~mW} / \mathrm{cm}^{2}$ ).

\subsection{Synthesis of TiOPc derivatives $\mathbf{3 a}$ and $\mathbf{3 b}$}

In the first step, alkoxyphthalonitriles were formed from 4-hydroxyphthalonitrile and 1-bromohexadecane or 1-bromotetradecane. 4-Hydroxyphthalonitrile $(0.72 \mathrm{~g}, 5 \mathrm{mmol})$ and dry potassium carbonate (5.52 g, $40 \mathrm{mmol}$ ) was stirred for $30 \mathrm{~min}$ under $\mathrm{N}_{2}$ gas in NMP, then a solution of 1bromohexadecane or 1-bromotetradecane $(10 \mathrm{mmol})$ in NMP was added and the mixture was stirred for $12 \mathrm{~h}$ at room temperature. The reaction mixture was filtered and purified by chromatography on a silica column with dichloromethane as the eluent. Yield: $92 \%(2 \mathrm{a})$ and $79 \%(2 \mathrm{~b})$.

2a; FT-IR ( $\left.\mathrm{KBr}, \mathrm{cm}^{-1}\right)$ : 2917, 2852 (C-H str.), $2232(\mathrm{C} \equiv \mathrm{N}), 1601,1562$ (Ar. C=C str.), $1475\left(\mathrm{CH}_{2}\right.$ bend), 1429 ( $\mathrm{CH}_{3}$ bend), 1308, 1251 (C-O); ${ }^{1} \mathrm{H}-\mathrm{NMR}(\delta)$ 7.72, 7.25, 7.20 (Ar. C-H), 4.05 (-O-CH $\left.2^{-}\right)$, $1.83\left(-\mathrm{O}-\mathrm{CH}_{2}-\mathrm{CH}_{2}-\right), 1.60\left(-\mathrm{CH}_{2}-\mathrm{CH}_{3}\right), 1.46,1.27\left(-\mathrm{CH}_{2}-\right), 0.89\left(-\mathrm{CH}_{3}\right)$; Anal calc. for $\mathrm{C}_{22} \mathrm{H}_{32} \mathrm{~N}_{2} \mathrm{O}: \mathrm{C}$ 77.60, H 9.47, N 8.23, O 4.70; found : C 76.30, H 12.20, N 8.17; MS: 340; 2b; FT-IR $\left(\mathrm{KBr}, \mathrm{cm}^{-1}\right)$ : 2917, 2851 (C-H str.), $2232(\mathrm{C} \equiv \mathrm{N}), 1603,1562$ (Ar. $\mathrm{C}=\mathrm{C}$ str.), $1475\left(\mathrm{CH}_{2}\right.$ bend), $1431\left(\mathrm{CH}_{3}\right.$ bend), 1308, 1252 (C-O); ${ }^{1} \mathrm{H}-\mathrm{NMR}(\delta)$ 7.74, 7.29, 7.20 (Ar. C-H), 4.06 (-O-CH$\left.{ }_{2}-\right), 1.86\left(-\mathrm{O}-\mathrm{CH}_{2}-\mathrm{CH}_{2}-\right), 1.60$ $\left(-\mathrm{CH}_{2}-\mathrm{CH}_{3}\right), 1.46,1.27\left(-\mathrm{CH}_{2}-\right), 0.89\left(-\mathrm{CH}_{3}\right)$; Anal calc. for $\mathrm{C}_{24} \mathrm{H}_{36} \mathrm{~N}_{2} \mathrm{O}: \mathrm{C} 78.21, \mathrm{H} 9.85, \mathrm{~N} 7.60, \mathrm{O}$ 4.34; found : C 79.22, H 13.31, N 8.02; MS: 368;

The second step was the base catalyzed cyclotetramerization of the phthalonitriles. A mixture of alkoxyphthalonitrile (4 mmol), Ti(OBu $)_{4}(0.37 \mathrm{~g}, 1.1 \mathrm{mmol})$, urea $(0.12 \mathrm{~g}, 2 \mathrm{mmol})$, and 1-octanol was heated at $150{ }^{\circ} \mathrm{C}$ under $\mathrm{N}_{2}$ for $24 \mathrm{~h}$. After the addition of methanol to the reaction mixture followed by refluxing for $30 \mathrm{~min}$, the resulting deep green blue crystals were collected by filtration, washed with methanol, and then dried in a vacuum oven at $100{ }^{\circ} \mathrm{C}$. Yield: $24 \%$ (3a) and $21 \%$ (3b).

3a; FT-IR ( $\mathrm{KBr}, \mathrm{cm}^{-1}$ ) : 2920, 2850 (C-H str.), 1607, 1529 (Ar. C=C str.), 1529, $1468\left(\mathrm{CH}_{2}\right.$ bend), 1383, 1344, 1282 (C-N), 1244, 1120 (C-O), 1074, 1016, 965, 749 (Ti-N); MS MALDI-TOF: 1364 $\left(\mathrm{MH}^{+}\right)$, 3b; FT-IR $\left(\mathrm{KBr}, \mathrm{cm}^{-1}\right):$ 2915, 2854 (C-H str.), 1752, 1607, 1531 (Ar. C=C str.), 1492, 1464 $\left(\mathrm{CH}_{2}\right.$ bend), 1367, 1343, $1302(\mathrm{C}-\mathrm{N}), 1237,1120(\mathrm{C}-\mathrm{O}), 1073,1016,964,750$ (Ti-N); MS MALDITOF: $1476\left(\mathrm{MH}^{+}\right)$. 


\subsection{Fabrication of DSSC devices}

We prepared DSSC devices using a quasi-solid state electrolyte containing $\mathbf{3 a}$ or $\mathbf{3 b}$ as an additive sandwiched with $\mathrm{TiO}_{2}$ adsorbed dyes and Pt-coated electrode as the two electrodes. The structure of the DSSC device is shown in Figure 7. The $\mathrm{FTO} / \mathrm{TiO}_{2} / \mathrm{Dye} /$ Electrolyte/Pt device was fabricated using the following procedure; a volume of ca. $10 \mu \mathrm{L} / \mathrm{cm}^{2}$ of the transparent paste (Ti-Nanoxide HT) was spread on FTO glass by the doctor blade method. After heating the FTO glass covered with $\mathrm{TiO}_{2}$ nanoparticles successively at ca. $100{ }^{\circ} \mathrm{C}$ and ca. $450{ }^{\circ} \mathrm{C}$ for about $30 \mathrm{~min}$ each, the sintering process was completed and the $\mathrm{TiO}_{2}$ deposited electrode was cooled down from $100{ }^{\circ} \mathrm{C}$ to ca. $60{ }^{\circ} \mathrm{C}$ at a controlled cooling rate $\left(5^{\circ} \mathrm{C} / \mathrm{min}\right)$ to avoid the cracking of the glass. A Pt counter electrode was fabricated by spreading on FTO glass using the doctor blade method. After heating the FTO glass spread Pt catalyst T/SP at $100{ }^{\circ} \mathrm{C}$ for $10 \mathrm{~min}$, it was fired at $400{ }^{\circ} \mathrm{C}$ for $30 \mathrm{~min}$. N3 dye was dissolved in absolute ethanol at a concentration of $20 \mathrm{mg}$ per $100 \mathrm{~mL}$ of solution. Nanoporous $\mathrm{TiO}_{2}$ film was dipped in this solution at room temperature for 24 hours. Afterwards, the dye-sensitized $\mathrm{TiO}_{2}$ electrode was rinsed with absolute ethanol and dried in air. Without a sealant, the electrolyte solution was cast onto the $\mathrm{TiO}_{2}$ electrode impregnated with $\mathrm{N} 3$ dye and then dried at $55{ }^{\circ} \mathrm{C}$ for 2 hours. The electrolyte solution was composed of $24 \mathrm{mg}$ of $\mathrm{I}_{2}, 72 \mathrm{mg}$ of TBAI, $80 \mathrm{mg}$ of PMImI as an ionic liquid, $0.32 \mathrm{~mL}$ of $\mathrm{EC} / 0.08 \mathrm{~mL}$ of $\mathrm{PC}(\mathrm{EC} / \mathrm{PC}=4 / 1$ as volume ratio) and $\mathbf{3 a}$ or $\mathbf{3 b}$ in acetonitrile solution.

Figure 7. The structure of $\mathrm{FTO} / \mathrm{TiO}_{2} / \mathrm{N} 3$ Dye/Electrolyte/Pt device using $\mathbf{3 a}$ and $\mathbf{3 b}$.

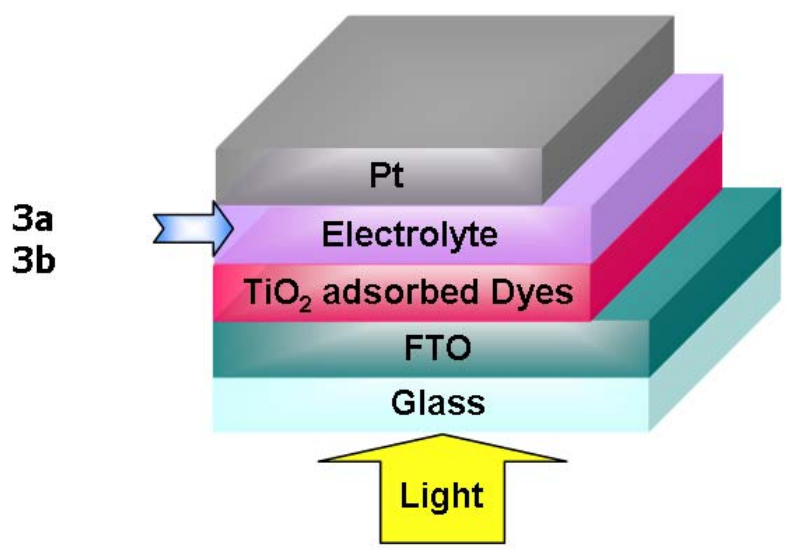

\section{Conclusions}

We have synthesized two kinds of TiOPc derivatives containing alkoxy groups, $\mathbf{3 a}$ and $\mathbf{3 b}$, and analyzed them by FT-IR, UV-vis and Fluorescence spectroscopy, XRD, and TEM. The optical properties of $\mathbf{3 a}$ and $\mathbf{3 b}$ were measured by UV-vis and fluorescence spectrophotometry. Both 3a and 3b showed high solubility in organic solvents such as chloroform, chlorobenzene, and dichloromethane. The quasi-solid DSSC devices prepared with a polymer electrolyte using $\mathbf{3 a}$ or $\mathbf{3 b}$ as an additive showed higher photovoltaic performance than the devices with a polymer electrolyte without 3a or $\mathbf{3 b}$, due to their increased $\mathrm{J}_{\mathrm{sc}}$ values. The best result obtained for the DSSC devices was a power conversion efficiency of 3.62 in the case of the DSSC device using PEG with $3 \mathrm{~b}$. Its Voc, $\mathrm{J}_{\mathrm{sc}}$, and FF were $0.66 \mathrm{~V}, 10.04 \mathrm{~mA} / \mathrm{cm}^{2}$ and 0.54 , respectively. 


\section{Acknowledgements}

This research was financially supporting by the Ministry of Education, Science Technology (MEST) and Korea Industrial Technology Foundation (KOTEF) through the Human Resource Training Project for Regional Innovation.

\section{References and Notes}

1. O'Regan, B.; Grätzel, M. A low-cost, high-efficiency solar cell based on dye-sensitized colloidal $\mathrm{TiO}_{2}$ films. Nature 1991, 353, 737-740.

2. Nazeeruddin, M.K.; Key, A.; Rodico, I.; Humphry-Baker, R.; Muller, E.; Liska, P.; Vlachopoulos, N.; Grätzel, M. Conversion of Light to Electricity by cis- $\mathrm{X}_{2} \mathrm{Bis}$ (2,2'-bipyridyl-4,4'dicarboxylate)ruthenium(II) Charge-Transfer Sensitizers ( $\mathrm{X}=\mathrm{Cl}^{-}, \mathrm{Br}^{-}, \mathrm{I}^{-}, \mathrm{CN}^{-}$, and $\left.\mathrm{SCN}^{-}\right)$on Nanocrystalline $\mathrm{TiO}_{2}$ Electrodes. J. Am. Chem. Soc. 1993, 115, 6382-6390.

3. Smestad, G.; Bignozzi, C.; Argazzi, R. Testing of dye sensitized $\mathrm{TiO}_{2}$ solar cells I: Experimental photocurrent output and conversion efficiencies. Sol. Energy Mater. Sol. Cells. 1994, 32, 259-272.

4. Hara, K.; Sayama, K.; Ohga, Y.; Shinpo, A.; Suga, S.; Arakawa, H. A coumarin-derivative dye sensitized nanocrystalline $\mathrm{TiO}_{2}$ solar cell having a high solar-energy conversion efficiency up to 5.6\%. Chem. Commun. 2001, 6, 569-570.

5. Chen, J.; Too, C.O.; Burrel, A.K.; Collis, G.E.; Officer, D.L.; Wallace, G.G. Photovoltaic devices based on poly(bis-terthiophenes) and substituted poly(bisterthiophene). Synth. Met. 2003, 137, 1373-1374.

6. Li, G.; Shrotriya, V.; Yao, Y.; Yang, Y. Investigation of annealing effects and film thickness dependence of polymer solar cells based on poly(3-hexylthiophene). J. Appl. Phys. 2005, 98, 043704/1-043704/5.

7. Tennakone, K.; Kumara, G.R.R.A.; Kottegoda, I.R.M.; Wijayantha, K.G.U.; Perera, V.P.S. A solidstate photovoltaic cell sensitized with a ruthenium bipyridyl complex. J. Phys. D Appl. Phys. 1998, 31, 1492-1496.

8. O’Regan, B.; Schwartz, D.T.; Zakeeruddin, S.M.; Grätzel, M. Electrodeposited nanocomposite np heterojunctions for solid-state dye-sensitized photovoltaics. Adv. Mater. 2000, 12, 1263-1267.

9. Woehrle, D.; Eskes, M.; Shigehara, K.; Yamada, A. A simple synthesis of 4,5-disubstityted 1,2dicyanobenzenes and 2,3,9,10,16,17,23,24-octasubstituted phthalocyanines. Synthesis 1993, 2, 194-196.

10. Bach, U.; Lupo, D.; Comte, P.; Moser, J.E.; Weissőrtel, F.; Salbeck, J.; Spreitzer, H.; Grätzel, M. Solid-state dye-sensitized mesoporous $\mathrm{TiO}_{2}$ solar cells with high photon-to-electron conversion efficiencies. Nature 1998, 395, 583-585.

11. Gebeyehu, D.; Brabec, C.J.; Sariciftci, N.S.; Vangeneugden. D.; Kiebooms, R.; Vanderzande, D.; Kienberger, F.; Schindler, H. Hybrid solar cells based on dye-sensitized nanoporous $\mathrm{TiO}_{2}$ electrodes and conjugated polymers as hole transport materials. Synth. Met. 2002, 125, 279-287.

12. Grant, C.D.; Schwartzberg, A.M.; Smestad. G.P.; Kowalik, J.; Tolbert, L.M.; Zhang, J.Z. Characterization of nanocrystalline and thin film $\mathrm{TiO}_{2}$ solar cells with poly(3-undecyl-2,2'bithiophene) ans a sensitizer and hole conductor. J. Electroanal. Chem. 2002, 522, 40-48. 
13. Bach, U.; Tachibana, Y.; Moser, J.E.; Haque, S.A.; Durrant, J.R.; Grätzel, M.; Klug, D.R. Charge Separation in Solid-State Dye-Sensitized Heterojunction Solar Cells. J. Am. Chem. Soc. 1999, 121, 7445-7446.

14. Li, W.; Kang, J.; Li, X.; Fang, S.; Lin, Y.; Wang, G.; Xiao, X. A novel polymer quaternary ammonium iodide and application in quasi-solid-state dye-sensitized solar cells. J. Photochem. Photobiol. A 2005, 170, 1-6.

15. Matsumoto, H.; Matsuda, T.; Tsuda, T.; Hagiwara, R.; Ito, Y.; Miyazaki, Y. The application on room temperature molten salt with low viscosity to the electrolyte for dye-sensitized solar cell. Chem. Letters. 2001, 1, 26-27.

16. Wang, H.; Liu, X.; Wang, Z.; Li. H.; Li, D.; Meng, Q.; Chen. L. Effect of Iodine Addition on Solid-State Electrolyte LiI/3-Hydroxypropionitrile (1:4) for Dye-Sensitized Solar Cells. J. Phys. Chem. B 2006, 110, 5970-5974.

17. Xue, B.; Wang, H.; Hu, Y.; Li, H.; Wang, Z.; Meng. Q.; Huang. X.; Sato, O.; Chen, L.; Fujishima, A. An alternative ionic liquid based electrolyte for dye-sensitized solar cells. Photochem. Photobiol. Sci. 2004, 3, 918-919.

18. Ng, D.K.P. Dendritic phthalocyanines: Synthesis, photophysical properties, and aggregation behavior. C.R. Chimie. 2003, 6, 903-910.

19. Gurek, A.G.; Bekaroglu, O. Tetrathia-macrocycle-bridged dimeric with hexakis(alkylthio) substituents and network polymer phthalocyanines. J. Porph. Phthalocyan. 1997, 1, 227-237

20. Lee, H.J.; Kim, W.S.; Park, S.H.; Shin, W.S.; Jin, S.H.; Lee, J.K.; Han, S.M.; Jung, K.S.; Kim, M.R. Effect of nanocrystalline porous $\mathrm{TiO}_{2}$ films on interface adsorption of phthalocyanines and polymer electrolytes in dye-sensitized solar cells. Macromol. Symp. 2006, 235, 230-236.

21. Han, D.S.; Li, Y.J.; Kim, J.S.; Kim, E. Effect of bridging group in poly(titanyloxophthalocyanine)s on photocurrent generation. Synth. Met. 1999, 101, 62-63.

22. Han, D.S.; Lee, Y.J.; Kim, J.S.; Kim, E. Photocurrent generation of poly(titanyloxophthalocyanine)s and silica hybrid film. Synth. Met. 2001, 117, 203-205

23. Yao, J.; Yonehara, H.; Pac, C. A Convenient Synthetic method for pure oxo(phthalocyaninato)titanium(IV) and application to other metal phthalocynines. Bull. Chem. Soc. Jpn. 1995, 68, 1001-1005.

24. Saito, T.; Iwakabe, Y.; Kobayashi, T.; Suzuki, S.; Iwayanagi, T. Thermochromism of specific crystal form oxotitanium phthalocyanines studied by electroabsorption and X-ray diffraction measurements. J. Phys. Chem. 1994, 98, 2726-2728.

(C) 2008 by the authors; licensee Molecular Diversity Preservation International, Basel, Switzerland. This article is an open-access article distributed under the terms and conditions of the Creative Commons Attribution license (http://creativecommons.org/licenses/by/3.0/). 